\title{
Nano-Engineered Scaffold for Osteoarticular Regenerative Medicine
}

Pascale Schwinté ${ }^{1,2, \$}$, Laetitia Keller ${ }^{1,2, \$}$, Stéphanie Lemoine ${ }^{1,2}$, Jacques-Eric Gottenberg ${ }^{1}$, Nadia Benkirane-Jessel ${ }^{1,2}$ and Maximilien Vanleene ${ }^{1,2 *}$

${ }^{1}$ INSERM, UMR 1109, Osteoarticular and Dental Regenerative Nanomedicine" laboratory, FMTS, Faculté de Médecine, F-67085 Strasbourg Cedex, France 2Université de Strasbourg, Faculté de Chirurgie Dentaire, 1 place de l'Hôpital, F-67000 Strasbourg, France

\begin{abstract}
In the last decade, regenerative medicine has benefited from the exponential development of nanomaterial sciences, tissue engineering and cell-based therapies. More and more sophisticated designed structures and surface topologies are being developed to basically mimic the extracellular matrix of native tissues such as cartilage and bone. Here we give an overview of the progress made in osteochondral lesion repair, with nano-engineered scaffolds comprising building blocks such as nanoparticles, nanotubes, layer-by-layer nano-assemblies, molecular self-assembly, nanopatterned surfaces.... This nano-engineering technology is coupled with bio-functionalization, by the use of adhesion peptides, growth factors, or deoxyribonucleic acid, to drive cell adhesion, proliferation and behavior towards tissue regeneration. In osteochondral regeneration, the challenge is the simultaneous development of chondrocytes and cartilage extracellular matrix on the one side and a well vascularized bone tissue with osteoblasts on the other side.
\end{abstract}

Keywords: Biocompatible scaffolds; Osteochondral lesion; Regenerative nanomedicine; Nanostructures; Bone; Cartilage; Tissue engineering

\section{Introduction}

Bone and cartilage tissue defects can be caused by bone tumor, osteomyelitis, periodontitis, and heavy traumatic fractures or by increasingly frequent osteochondral degenerative diseases (osteoporosis, arthrosis...) particularly in the developed countries due to population ageing $[1,2]$. Osteochondral defects are critical and difficult clinical problems in orthopedic surgery and impose a growing burden on society, in terms of human costs (pain, loss of mobility, morbidity), or social welfare costs (treatment, rehabilitation and sick leaves).

Despite the overall capacity of bone to regenerate, bone defects can be long, difficult or even sometimes impossible to heal if the defect reaches a critical size or is originally caused by an impaired capacity to regenerate. Contrary to bone, cartilage tissue has very little to no capacity to heal, due to its avascular nature, and to the chondrocyte low population density, impaired migration and proliferation [3-5]. Therefore, the development of biomaterials and implementation of tissue engineering techniques are necessary to treat these defects, by promoting and accelerating bone and cartilage tissue regeneration. To efficiently support and direct cells towards new osteochondral tissue formation, such biomaterials scaffolds need to mimic the tissue extracellular matrix (ECM) at the microscopic and nanoscopic scale. Recently, regenerative medical research has particularly focused on improving the scaffold biocompatibility using innovative nanostructures such as nanogrooves [6,7], nanofibers $[8,9]$, carbon nanotubes $[10,11]$ and graphene [12-14] allowing better cells' adhesion, organization and morphology and exhibiting other interesting properties (electrical conductivity [8], cell force biosensors [15], detoxification [16,17]). Nanotechnologies can also be used to improve the scaffold bioactivation (nanoparticles, nanoreservoirs, protein adsorption...) allowing a better spatial or chronological release control over the bioactive agent (growth factors, cytokines...) $[18,19]$.

\section{Bone and Cartilage Structure and Function}

Bone main function is to provide rigidity to the body but also mineral ion homeostasis and protection for hematopoietic and progenitor cells. To obtain rigidity with minimal weight, bone presents a hierarchized architecture, from the molecular scale, with collagen type I molecules (90\% of the bone matrix protein) and apatite crystals organized, at the nanoscale, into mineralized collagen micro-fibrils and fibers. Those fibers are themselves organized at the microscopic scale into the cortical bone osteons' concentric lamellae or organized into trabecular bone beams. Those cortical and trabecular bone tissues form respectively the strong shell or the filling of epiphysis cavities at the bone organ scale [20].

Bone mechanical properties depend not only on its macroscopic geometry (cortex thickness and moment of inertia, trabecular bone volume) but also on the bone tissue intrinsic properties [21] which strongly depend on the porosity and mineralization at the millimeter scale [22]. However, bone microscopic and nanoscopic structures play also an important role on its toughness [23,24]. Bone also exhibits anisotropic and heterogeneous elasticity at the microscopic scale $[25,26]$ as well as a weaker influence of mineralization [27]. This points out a greater contribution of bone nanostructures to its mechanical behaviors, which is still not fully understood.

Hyaline articular cartilage plays an extremely important role in the osteo-articular system, allowing frictionless sliding and excellent congruency between articular surfaces and protecting the subchondral bone from impacts and compressive loads. Cartilage presents a fibrous ECM made of collagen type II, proteoglycans, glycoamino glycans (GAG) and water with no vascularization and a low chondrocyte cell density (1\% of the tissue volume) [28]. Cartilage ECM exhibits an inhomogeneous and anisotropic structure with four distinct zones: a superficial zone with dense layer of fibers parallel to the cartilage

*Corresponding author: Maximilien Vanleene, Université de Strasbourg, Faculté de Chirurgie Dentaire, 1 place de l'Hôpital, F-67000 Strasbourg, France, Tel: 33-0368853376; E-mail: mvanleene@gmail.com

\section{Author Contributions: §}

These authors have equally contributed to this work

Received November 19, 2014; Accepted December 24, 2014; Published January 01,2015

Citation: Schwinté P, Keller L, Lemoine S, Gottenberg JE, Benkirane-Jessel N, et al. (2015) Nano-Engineered Scaffold for Osteoarticular Regenerative Medicine. J Nanomed Nanotechnol 6: 258. doi: 10.4172/2157-7439.1000258

Copyright: @ 2015 Schwinte $P$, et al. This is an open-access article distributed under the terms of the Creative Commons Attribution License, which permits unrestricted use, distribution, and reproduction in any medium, provided the original author and source are credited. 
surface and resisting the shear forces, a transitional zone with randomly oriented collagen fibers and proteoglycans, a thick middle zone with a high proteoglycans density and large collagen fibers perpendicular to the surface allowing a strong fixation into the basal layer of mineralized cartilage zone [4]. Variation of tissue density, composition and orientation of the fibers throughout the cartilage thickness and the complex interaction between collagen, proteoglycans and GAGs give a soft, porous, permeable but resistant ECM able to bare high compressive loads.

Unlike other tissues like bone, cartilage does not heal and the degradation etiology is still not understood [29]. Some mechanical, chemical and cellular causes of superficial cartilage lesions have been identified but a major role of the subchondral bone has been highlighted on the initiation or the propagation of the failure [30,31]. A superficial lesion can cause a thickening of the subchondral bone deeper, which exacerbates the superficial defect and induces joint destabilization and extreme pain [31]. In fact, cartilage and subchondral bone should not be considered separately but as a unique and complex osteochondral entity and therapy should treat both to obtain long term restoration of the joint.

The current technique to treat bone and cartilage defects is to perform autologous grafts using the patient bone (usually from the iliac crest) $[1,2]$ and small cylindrical tissue plugs from unaffected cartilage (mosaicplasty) [3,31]. Autograft implantation has however serious drawbacks (heavy surgical procedures, patient's pain and site morbidity, infection risks and limited tissue volume available). Use of allograft is an alternative but increases the patient's risks (graft immune rejection and donor's disease transmission) while providing a limited efficiency (increased graft resorption) [1,2]. Rather high rates of failure were reported for both types of grafting (13-30\% and 25$30 \%$ respectively) [1]. Alternative ways from material and life sciences were developed using artificial implants to treat the defects. First, orthopedic therapies aimed to restore the bone and cartilage functions with orthopedic prostheses initially inert and then bioactivated to improve biological integration. Then, more recently, tissue engineering attempted to regenerate new tissues by use of biomaterials scaffolds eventually coupled with cell-based therapy. Replacement and regeneration of the osteochondral tissue constitute a major challenge in modern regenerative medicine and require the development of biomaterials mimicking the microscopic and nanoscopic features of the osteochondral tissue ECM using nanostructures (nanofibers, nanotubes or nanopatterned surfaces) and incorporating bioactive molecules (cytokines, growth factors) in order to improve cell adhesion, proliferation and to orientate their behaviors towards tissue regeneration as illustrated in the Figure 1.

\section{Biomaterials and their Design for Bone and Cartilage Regeneration}

In order to quickly and satisfactorily repair the bone and cartilage defects, several requirements must be fulfilled in the biomaterial at the macro-, micro- and nanoscale. The biomaterial must be biocompatible and biodegradable while presenting sufficient mechanical properties to temporarily perform the native tissue functions and support the cells during the formation of the new tissue [32]. The implant must also be osteochondro-conductive and osteochondro-inductive, promoting cell optimal organization and behavior (adhesion, proliferation, migration, differentiation and gene expression) towards the construction of bone and cartilage ECM and the regeneration of the native tissues [1$3,5,32,33]$.

The implants intend to mimic the native tissue feature presenting a three dimensional microstructure to support the cells. 3D scaffolds and hydrogels have been shown to promote a more natural cell behavior (differentiation, gene expression, ECM fabrication) and tissue organization than $2 \mathrm{D}$ implants $[4,8,29,34]$. For example, autologous chondrocyte implantation (ACI) procedure consisting in injecting patient's chondrocytes in articular defects and covering it with a periosteum or collagen membrane, gave mixed results with often apparition of fibrous cartilage tissue instead of hyaline cartilage. The technique evolved towards a Matrix-induced ACI with chondrocytes grown within a $3 \mathrm{D}$ scaffold, and presented better results on the long

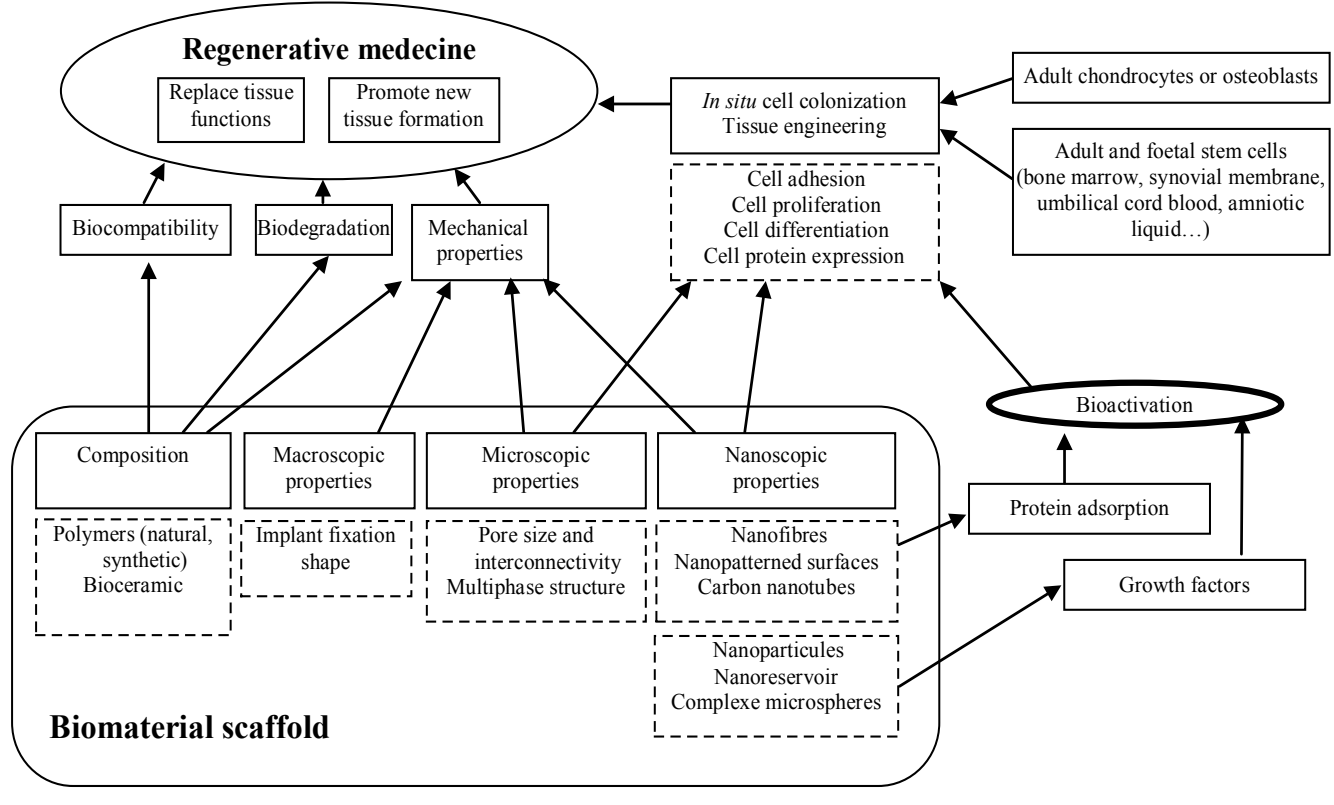

Figure 1: Illustration of scaffold nanostructural properties requirements for successful osteochondral tissues regeneration. 
term. [3-5,31] Another requirement is scaffold high micro-porosity with optimized pore dimension $(200-400 \mu \mathrm{m})$ and interconnectivity to allow the cells to migrate inside the scaffold and to allow the diffusion of nutriments and wastes $[2,34]$.

For the last twenty years, scaffolds and hydrogels developed were either made of natural polymers (collagen, alginate, chitosan (CHI), hyaluronic acid, silk...) or synthetic polymers (poly(Llactic) acid (PLLA), polyglycolic acid (PGA), polycaprolactone (PCL), poly(lactide-co-glucolide (PLG), poly(ethylene oxide) $(\mathrm{PEO}), \ldots)$. $[1-4,29,35,36]$. Although natural polymers allow to build biocompatible and biodegradable scaffolds with excellent cell-matrix interaction, some concerns have been raised about the molecule amount availability and composition variability, about the degradation rate control and the possibility of immune response [36]. On the contrary, synthetic materials are easier to obtain in a reproducible way and have predictable and tunable properties $[2,35]$ but have usually poor bioactivity and low mechanical properties. On the other hand, other materials such as calcium phosphates (hydroxyapatite (HA), $\beta$-tricalcium phosphate) and bioglass present good osteoconductivity and rigidity but are considered as fragile [37-41]. To overcome their limitations and combine their advantages, polymers and bioceramics have been combined to form microporous biocomposites for bone regeneration purposes [32,35,42-44]. A review of the scaffold manufacturing techniques can be found in Lee et al. [34] and Rezwan et al. [35]. Multiphase scaffolds have also been investigated to mimic the stratified structure and mechanical properties of the osteochondral unit by varying the polymer composition, the bioglass or HA incorporation and the phase porosity [45-48].

\section{Nanostructured Biomaterials}

In the last ten years, nanotechnologies have emerged as powerful tools to better mimic the nanostructure of the bone and cartilage ECMs and therefore to better drive the cells behavior. As cartilage and bone ECMs are made of nanoscopic fibrils and crystals, a first approach was to provide biomaterials with surfaces presenting nanotopographic features which improve interactions with the cells [8-10].

\section{Nanopatterned surfaces and nanotubes}

Due to a very high surface to volume ratio, surface nanoscopic features such as nanogrooves, grating, surface roughness, nanopits, etc., engineered using nanolithography, chemical vapor deposition, electrochemical etching, oxidative nano-patterning etc., have been shown to improve the surface protein adsorption, cell adhesion, osteogenic differentiation and behavior [6,7,11,49-54]. Nanotopographic surface enhancement can also be found in the form of nanotubes (carbon, titanium, tantalum) deposited inside scaffolds or implant surface [8-10,55]. For example, titanium implants coated with carbon nanotubes (CNTs) exhibited an excellent in vivo osteointegration with bone tissue growth, mineralization and no sign of inflammation [56]. As well, titanium oxide $\left(\mathrm{TiO}_{2}\right)$ and tantalum nanotubes were shown to promote osteoblasts viability, elongated cell morphology (compared to spread cells on flat surface) and osteogenic activities (alkaline phosphatase ALP, mineralized bone nodules) [57]. Anodized $\mathrm{TiO}_{2}$ nanotubes were also found to be chondrogenic with production of a dense ECM with GAGs and collagen type II when seeded with chondrocytes [58]. Nanotubes integrated within a nanocomposite made of CHI nanofibres, and apatite nanocrystals exhibited improved surface hydrophilicity, osteoblast adhesion and proliferation in vitro [59]. Recently, a renewed interest has been developed upon the carbon mono-layered graphene and its variants (graphene oxide, GO) [60] due to its good biocompatibility [61] but also its possible uses as biosensors [55,62-64]. Graphene can be used in different forms (monolayer nanoplatelets, nanoribbons, nanotubes) and can easily be integrated within the cells showing excellent capacity as drug delivery carrier $[65,66]$. Graphene oxide can be also integrated within biomaterials to improve the osteogenic differentiation of the cells. Depan et al. [14] described the synergic effects of a HA-graphene oxide-CHI hybrid on MC3T3-E1 pre-osteoblasts cells, promoting the cells adhesion, proliferation, osteogenic differentiation and mineralization. As well, Nayak et al. [13] described an efficient osteogenic differentiation of human mesenchymal stem cells cultivated on graphene coated surfaces.

\section{Nanofibrous scaffolds}

Nanofibrous scaffolds have been particularly investigated due to their ability to mimic the ECM nanofibres of bone (collagen I) or cartilage (collagen type II, hyaluronic acid, GAGs...) and have strong osteogenic and chondrogenic properties when fibers diameter is less than $1 \mu \mathrm{m}$ [9]. Nanofibrous scaffolds can be manufactured by selfassembly, electrospinning and phase separation techniques [59,67-73]. Molecular self-assembly consists in the spontaneous organization of the molecules such as collagen [74,75], or peptide amphiphiles [72] under thermodynamic equilibrium conditions. Using this technique, Lee et al. were able to produce peptide amphiphile nanofibres cleverly bioactivated with bone morphogenetic proteins BMP-2 (see bioactivated scaffolds paragraph below) and to obtain excellent in vivo bone defect regeneration [72]. Other similar self-assembly constructs have displayed many binding domains for growth factor TGF- $\beta 1$, resulting in chondrogenesis from mesenchymal stem cells and cartilage regeneration in a rabbit model [76]. Self-assembling amino-acids forming $\beta$-sheets were used by Liu et al. leading to chondrocytes growth and hyaline cartilage production [77] and chondrocyte differentiation from bone marrow stem cells [78]. However, these synthetic peptides may lack proper cell adhesion sites, which have to be added, and they can induce local acidic $\mathrm{pH}$ due to hydrolysis, with possible inflammatory reaction [79]. Nanofibrous scaffolds can also be obtained by thermally induced phase separation (TIPS) when a polymer solution is made thermally instable leading to a polymer rich phase solidifying while the solvent rich phase is removed. Wei et al. [71] obtained $90 \%$ porous nanofibrous PLLA scaffold with bound HA nanocrystals and showing four times more protein adsorption than flat surfaced scaffold. Associated with particle leaching technique, Woo et al. [73] and Sachar et al. [69] investigated respectively a PLLA and gelatin 3D nanofibrous scaffold seeded with osteoblasts and observed an osteogenic behavior with long shaped cells and aggregation, osteoblastic genes expression (collagen, bone sialoprotein, osteocalcin, integrins...), matrix deposition and mineralization.

The electrospinning technique consists in inducing high static electrical charges on the molecules of a polymer solution until the applied electrical forces cause the liquid to stretch and form a polymer continuous jet. The solution jet evaporates, solidifies to form a fiber and is then collected as a randomly oriented nanofibrous matrix on a grounded collector. Nanofibres dimensions can be down to the nanometer size and can be orientated by various collector designs: collector grids, rotating rod collector, electrode collector systems, fluids... Electrospun nanofibrous matrices do not display large pores and are not very thick due to the slow fiber production rate which imply the use of combined techniques (hydrogels, rapid prototyping, salt particles leaching...) [67]. The electrospinning technique is however extremely popular and has been widely used for osteochondral scaffolds investigations [8]. Numerous natural polymers (collagen [80], CHI 
[81], silk [82]) and synthetic polymers (PCL [68,83-86], polyurethane [87], PLA [88]...) have been investigated to make osteogenic electrospun nanofibrous scaffolds, with success [55]. Incorporation of HA nanocrystals $[80,87]$, carbon nanotubes with electrical current [88], mixed polymers $[82,89]$ or micro-nano combined structures [90] have been also investigated in order to improve the mechanical properties and cell adhesion, proliferation and differentiation. By varying the fiber size and orientation and using porogens, McCullen et al. [84], Accardi et al. [85] and Steele et al. [86] attempted to replicate the multiphase zonal structure of the cartilage tissue. The anisotropic multiphase nanofibrous matrices obtained exhibited better mechanical properties (compressive and tensile) compared to randomly oriented nanofibres [84] and shear damages observed were related to the shear forces and fibers orientation (with more damage if shear forces were perpendicular to the fiber orientation) [85]. Seeded chondrocytes were able to proliferate, exhibiting elongated or rounded shapes in aligned or randomly oriented fibrous layers respectively and producing GAGS and collagen type II in all the layers [84,85,91]. Interestingly, in the bi-layered scaffold built by Steele et al. with a top electrospun PCL nanofibres layer on a porous PCL layer, chondrocyte proliferation was homogeneous in the scaffold but GAGs, collagen type II and proteoglycans expression were highest in the smaller pore size area [86]. In other attempts to elaborate multiphase scaffolds, Stanishevsky et al. have developed collagen fiber composites loaded with hydroxyapatite nanoparticles [92], and Catledge et al. have reported on a triphasic scaffold obtained by electrospinning a mixture of PCL, type I collagen and hydroxyapatite nanoparticles [93].

\section{Cell-substrate interactions}

Quick and successful regeneration of bone and cartilage is necessarily driven by osteochondral cells efficient adhesion, migration, proliferation and differentiation within the biomaterial implants. Those cells can either migrate from surrounding tissues in acellular scaffolds or be seeded (and eventually cultivated before implantation) from patients own osteochondral cells or stem cells (either adult or embryonic) $[3,5,94,95]$. Considering the ethical and safety concerns raised against the embryonic stem cells, adult mesenchymal stem cells (MSC) are considered as better candidates for osteochondral regenerative medicine as they are available from a large range of tissues, can easily expand and differentiate into bone and cartilage cells in an adequate environment $[94,95]$.

To be osteogenic, the nanostructured scaffold must provide chemical extracellular signals from the growth factors, cytokines (discussed in the following paragraph) but also some synergic physical features (high surface/volume ratio, nanotopography, 3D environment, substrate stiffness) which will shape cells capacities to interact with the ECM (cell's adhesion, morphology, aligning and "mechanosensing", ECM probing and deformation) and dictate the cells' osteochondral fate $[11,54,95,96]$.

Cell response to nanotopographic cues has demonstrated some specific nanostructure size range ( 3 to $29 \mathrm{~nm}$ ) which promotes cell adhesion and osteoblastic differentiation [11]. Nanotopographic cellular "sensing" have been shown to involve some specific cell membrane adhesive proteins (integrins, and focal adhesion complexes) and to recruit many cytoskeleton structures (actin, talin,...) involved in some complex cellular mechanotransduction pathways (focal adhesion kinase FAK, extracellular signal-regulated kinase ERK/MAPK, rhoA/ ROCK) [95]. Other cellular mechanosensors such as primary cilia and mechanosensitive ion channels have also been identified and might be involved in the same intracellular activation pathways [96]. Such mechanotransduction mechanisms allow the cell to sense the external applied forces (compression, tension, fluid shear stresses and hydrostatic pressure). Stem cells exposed to tensile stretching or better to fluid shear stresses were found to differentiate into osteoblasts [11] while exposure to combined compressive-shear stresses, fluid shear stresses or hydrostatic pressure promotes a chondrogenic differentiation [97,98]. The cell mechanosensitivity allows also the probing of the substrate and its interaction (fiber aligning, ECM maintenance) via cellular contractibility $[96,97]$. Cells are able to "measure" the matrix stiffness and to adapt accordingly towards chondrogenic differentiation on soft substrate or osteogenic differentiation on stiffer ones $[15,99]$. Such property can be used to control the stem cells differentiation by varying the substrate rigidity with nanoparticles integration (GO, CNTs, HA nanocrystals) [13,14].

\section{Biomaterial Nano-bioactivation}

As previously explained, cellular adhesion, proliferation and osteochondral differentiation are strongly influenced by the nanostructural properties of the biomaterial but can also be driven synergistically by additional bioactive molecules such as binding proteins or peptides or by growth factors [29]. Growth factors such as Bone Morphogenetic Proteins (BMP-2, BMP-7), Vascular Endothelial Growth Factors (VEGF), Transforming Growth Factors (TGF), Epithelial Growth Factors (EGF), Fibroblast Growth Factors (FGF), Insulin Growth Factors (IGF), can be used successfully to promote the proliferation or to drive the differentiation and the gene expression of the cells $[5,56,72]$.

Bioactive molecules can be injected locally in the healing area or directly incorporated into an implanted scaffold. Direct incorporation results generally in a short initial burst release and requires high dose of factors that can be detrimental to the surrounding tissue and cells (inflammation, cytotoxicity) [100]. Factors can also be directly embedded into the polymer (emulsion electrospinning, emulsion freeze drying) which allows a first burst release and then sustained slow release of the factors (several weeks). The matrix properties such as porosity or cross-linking degree will modulate the diffusion release of the growth factor $[101,102]$. The major drawbacks of this technique are a potential loss of bioactivity during the incorporation and a release rate dependent on the scaffold degradation which might not correspond to an optimized use of the factors. Various nanotechnology strategies can be used to protect the factors and to improve their release characteristics (duration, chronology, targeting, gradients...).

\section{Binding proteins and peptides}

Cell adhesion within the scaffold can be improved by addition of binding proteins or peptides such as integrins or the arginine-glycineaspartic acid (RGD) sequence [103]. More recently, integration of bone and cartilage matrix molecules such as heparin, or fibronectin into polymers have also been used to improve cell and bioactive molecule fixation [33]. Lee et al. [72] have for example developed an amphiphilic peptide able to bind a heparin sulphate-BMP-2 complex and fixed it inside a collagen scaffold. This peptide allowed binding of a very low dose of BMP-2 (11 $\mu \mathrm{g}$ compared to $12 \mathrm{mg}$ therapeutic doses) with a very slow release speed (roughly $23 \%$ after 8 days compared to $84 \%$ in a heparan sulphate gel). Quicker bone regeneration was observed in a bone critical size defect from rat model using the collagen- amphiphileheparane sulphate-BMP-2 hybrid scaffold.

\section{Nanostructured microspheres and nanoparticles}

Bioactive molecules (growth factors or DNA/RNA sequences) can 


\begin{tabular}{|c|c|c|c|}
\hline Nanostructured Materials & Fabrication techniques & Cell types & Cell behaviors \\
\hline $\mathrm{TiO}_{2}$ nanotubes with Ta coating [57] & $\begin{array}{l}\text { Two electrode setup anodization and } \\
\text { vacuum-deposited }\end{array}$ & Osteoblasts & $\begin{array}{l}\text { Improvement of viability and faster } \\
\text { mineralization }\end{array}$ \\
\hline $\mathrm{TiO}_{2}$ nanotubes [58] & Two electrode setup anodization & Chondrocytes & Promotion of chondrogenesis \\
\hline $\begin{array}{l}\text { Carbon nanotubes+ nanocomposite of } \mathrm{CHI} \\
\text { fibers+ HA crystals [59] }\end{array}$ & $\begin{array}{l}\text { Arc discharged method, freeze-drying } \\
\text { and lyophilization }\end{array}$ & Osteoblasts & Improvement of adhesion and proliferation \\
\hline Graphene oxide (GO) + CHI + HA [14] & $\begin{array}{l}\text { Covalent liaison of } \mathrm{CHI} \text { and } \mathrm{GO} \text { in } \\
\text { solution }\end{array}$ & MC3T3-E1 fibroblastic cells & $\begin{array}{l}\text { Improvement of adhesion, proliferation and } \\
\text { osteogenic differentiation }\end{array}$ \\
\hline Graphene oxide with PMMA [13] & Chemical vapor deposition & mesenchymal stem cells & Improvement of osteogenic differentiation \\
\hline $\begin{array}{l}\text { Collagen-GAG scaffolds with biomolecular } \\
\text { pattern (fibronectin) [49] }\end{array}$ & Direct photolithography & MC3T3-E1 fibroblastic cells & Improvement of the speed of cell attachment \\
\hline Nanostructured alumina surfaces [39] & Chemical vapor deposition & Osteoblasts & Induction of osteogenic differentiation \\
\hline $\begin{array}{l}\text { Polycrystalline titanium nanostructured surface } \\
\text { with conformal bioactive calcium phosphate } \\
\text { thin films sputter [50] }\end{array}$ & RF magnetron sputter deposition & $\begin{array}{l}\text { Bone marrow mesenchymal } \\
\text { stem cells }\end{array}$ & $\begin{array}{l}\text { Improvement of adherence, proliferation and } \\
\text { osteogenic differentiation }\end{array}$ \\
\hline $\begin{array}{l}\text { Electrochemically grooved nanostructured } \\
\text { stainless steel implant with pre-adsorption of } \\
\text { protein [51] }\end{array}$ & $\begin{array}{l}\text { Phase reversion-induced nanograined } \\
\text { structure }\end{array}$ & Osteoblasts & $\begin{array}{l}\text { Improvement of osteoblastic function and } \\
\text { activity }\end{array}$ \\
\hline $\begin{array}{l}\text { Micro- and nanopatterned transplantable } \\
\text { poly(lactic-co-glycolic acid) polymer [52] }\end{array}$ & $\begin{array}{l}\text { Capillary force lithography with a surface } \\
\text { micro-wrinkling }\end{array}$ & Mesenchymal stem cells & $\begin{array}{l}\text { Improvement of adhesion, osteogenic differentiation } \\
\text { and pattern-controlled bone regeneration }\end{array}$ \\
\hline $\begin{array}{l}\text { Patterned silicon topographically-patterned } \\
\text { surface [7] }\end{array}$ & Nanolithography & Mesenchymal stem cells & $\begin{array}{l}\text { Specific size scale of topographic cue promotes } \\
\text { osteogenic differentiation with or without } \\
\text { osteogenic agents }\end{array}$ \\
\hline $\begin{array}{l}\text { Carbon nanotubes -reinforced HA coating on } \\
\text { titanium implants [56] }\end{array}$ & Plasma-spray & Osteoblasts & CNT addition improves osseo integration \\
\hline $\begin{array}{l}\text { Nanofibrous } \mathrm{CHI} \text {-nanocrystalline HA scaffolds } \\
\text { with single-walled carbon nanotubes [59] }\end{array}$ & Freeze-drying and lyophilization & Osteoblasts & $\begin{array}{l}\text { Improvement of cytocompatibility for } \\
\text { osteoblasts adhesion and proliferation }\end{array}$ \\
\hline $\begin{array}{l}\text { Nanofibrous PCL with BMP-2 nanoreservoirs } \\
\text { [68] }\end{array}$ & $\begin{array}{l}\text { Electrospinning and layer by layer } \\
\text { deposition }\end{array}$ & Osteoblasts & $\begin{array}{l}\text { Improvement of osteogenic gene expression } \\
\text { and mineralization }\end{array}$ \\
\hline Nanofibrous gelatin [69] & $\begin{array}{l}\text { Thermally induced phase separation and } \\
\text { porogene-leaching }\end{array}$ & Osteoblasts & $\begin{array}{l}\text { Improvement of migration, proliferation and } \\
\text { mineralization }\end{array}$ \\
\hline $\begin{array}{l}\text { Collagen scaffold and heparin-binding peptide } \\
\text { amphiphiles with nanofiber-heparan sulfate [72] }\end{array}$ & Peptide synthesis & $\begin{array}{l}\text { In vivo implantation without } \\
\text { cells }\end{array}$ & Large volumes of regenerated bone \\
\hline Nano-fibrous Poly(I-lactic)acid scaffolds [73] & Freeze-drying and lyophilization & Osteoblasts & $\begin{array}{l}\text { Improvement of osteoblast phenotype, } \\
\text { mineralization and earlier differentiation }\end{array}$ \\
\hline $\begin{array}{l}\text { Supra- molecular self-assembled nanofibers of } \\
\text { peptide amphiphiles [76] }\end{array}$ & $\begin{array}{l}\text { Standard solid phase methods and self } \\
\text { assembly }\end{array}$ & Mesenchymal stem cells & $\begin{array}{l}\text { Improvement of viability and chondrogenic } \\
\text { differentiation }\end{array}$ \\
\hline $\begin{array}{l}\text { Peptide hydrogel KLD12 }\left([\mathrm{KLDL}]_{3}\right) \text { and } \\
\left.\text { RAD16-I ([RADA }]_{4}\right)\end{array}$ & Self assembly & $\begin{array}{l}\text { Chondrocytes [77] } \\
\text { Bone marrow stromal cells [78] }\end{array}$ & $\begin{array}{l}\text { Promotion of chondrogenesis } \\
\text { Promotion of chondrogenesis }\end{array}$ \\
\hline $\begin{array}{l}\text { Poly(lactic acid-co-glycolic acid) nanocapsules } \\
\text { with bone morphogenetic protein BMP-2 and } \\
\text { poly(3-hydroxybutyrate-co-3-hydroxyvalerate) } \\
\text { nanocapsules with BMP-7, embedded in CHI } \\
\text { scaffold [84] }\end{array}$ & Co-electrospinning & Bone marrow stromal cells & $\begin{array}{l}\text { Improvement of osteogenic differentiation } \\
\text { (ALP activity) }\end{array}$ \\
\hline $\begin{array}{l}\text { Nanofibrous } \mathrm{CHI} \text {, silk } \\
\text { Fibroin (SF) and CHI/SF [82] }\end{array}$ & Electrospinning & $\begin{array}{l}\text { Bone marrow mesenchymal } \\
\text { stem cells }\end{array}$ & $\begin{array}{l}\text { Promotion of proliferation and osteogenic } \\
\text { differentiation }\end{array}$ \\
\hline $\begin{array}{l}\text { Nanofibrous PCL with BMP-2 nanoreservoirs } \\
\text { [83] }\end{array}$ & $\begin{array}{l}\text { Electrospinning and layer by layer } \\
\text { deposition }\end{array}$ & Osteoblasts & Promotion of mineralization and proliferation \\
\hline $\begin{array}{l}\text { Nanofibrous PCL trilaminarcomposite scaffolds } \\
\text { [84] }\end{array}$ & Electrospinning & Chondrocytes & $\begin{array}{l}\text { Support chondrogenesis and higher } \\
\text { mechanical properties }\end{array}$ \\
\hline Aligned nanofibrous PCL [85] & Electrospinning & Chondrocytes & Higher resistance to damage \\
\hline Bilayered nanofibrous PCL [86] & Electrospinning & $\begin{array}{l}\text { Chondrocytes correct } \\
\text { topology }\end{array}$ & Promotion of chondrogenesis \\
\hline $\begin{array}{l}\text { Nanofibrous Polyurethane (PU) and PU-HA } \\
\text { composite [87] }\end{array}$ & Electrospinning & $\begin{array}{l}\text { Osteoblasts, embryonic } \\
\text { mesenchymal progenitor cells }\end{array}$ & $\begin{array}{l}\text { Higher mechanical properties and improvement } \\
\text { of bone matrix formation }\end{array}$ \\
\hline $\begin{array}{l}\text { Oriented and aligned nanofibres of } \\
\text { biodegradable poly-DL-lactide with embedded } \\
\text { multi-walled carbon nanotubes [88] }\end{array}$ & Electrospinning & Osteoblasts & Improvement of osteoblast functions \\
\hline Interspersed PLA and gelatin fibers [89] & Co-electrospinning & Chondrocytes & Improvement of proliferation and differentiation \\
\hline
\end{tabular}

Table 1: Summary of the osteochondro-inductive nanostructures presented and the cell behavior outcomes observed.

be integrated within a scaffold inside nanostructured microspheres or nanoparticles (NPs). Zhang et al. have written an exhaustive review of the nanoparticles available for growth factors: liposomes, lipid and polymer capsules, micelles, polymer NPs...[18]. Such release nanosystems improve the factors protection, allow a better control of their distribution (homogeneity, gradient) and fine tuning of their release rate. BMP-2, TGF- $\beta 1$, or IGF- 1 for instance were loaded in PLGA or PEG microspheres, resulting in good osteochondral regeneration $[19,104,105]$. BMP-2 and BMP-7 have been embedded within $\mathrm{CHI}$ nanofibres using two different polymers respectively (poly- 
lactic acid-co-glycolic acid (PLGA) and poly-3-hydroxybutyrateco-3-hydroxyvalerate (PHBV)) allowing a sequential release of the two factors and a synergic effect on the proliferation and osteogenic differentiation of the seeded mesenchymal stem cells [81]. Polymeric microspheres and nanoparticles can also be nanoengineered to improve their properties. Polyethylenimine (PEI)-albumin NPs used for BMP-2 delivery were modified with Poly-ethylene glycol to decrease PEI cytotoxicity allowing improved biocompatibility of the NPs and better bone formation despite a decreased fixation of BMP2 [106]. Microspheres can also be tuned by incorporation of HA nanocrystals to tune the factor release kinetics [107] or can present sophisticated core-shell architecture based on two different polymers (PLGA and alginate) loaded with different bioactive molecules (BMP2, dexamethasone) allowing an improved osteogenic effect on bone mesenchymal stem cells [108]. Recently, magnetic biocompatible scaffolds have been designed, containing magnetic nanoparticles allowing controlled release of growth factor by means of an external magnetic field $[109,110]$.

\section{Layer by layer deposition: nanocapsules and multilayered coatings}

A very effective way to control the growth factor fixation into a scaffold and tune its release kinetics is the use of the Layer-by-Layer (LBL) deposition consisting in successive coatings with oppositely charged polyelectrolytes $[68,83,111-113]$. In our laboratory, the LBL technique was used to make multilayered PGA/PLL nanocapsules and to fix two growth factors (BMP-2 and TGF- $\beta$ ). The nanoparticles incorporated inside alginate gel with mice embryonic stem cells (ESC) were able to initiate osteoblastic differentiation in vitro and to induce bone formation when the alginate-nanocapsules-ESC was injected subcutaneously [111]. The growth factors release was found to be controlled by the layer enzymatic degradation by the cells, allowing a very local and efficient release. The following investigations focused on the bioactivation of a PCL electrospun matrix via the building up of LBL nanoreservoirs. Mendoza-Palomares et al. demonstrated the osteogenic properties of dendrigraft poly(-L-Lysine) (DGL)/BMP-2 LBL nanoreservoirs on human osteoblasts, which efficiency was related to the number of deposited layers in the reservoirs [83]. Other polymers were also investigated (CHI, PLL) and displayed high osteogenic efficiency. Interestingly, the $\mathrm{CHI}$ nanoreservoirs displayed a fish-scale sharp shape while the PLL nanoreservoirs were smooth-shaped. This nanotopographic difference may explain the better osteogenic results observed with CHI- based nanoreservoirs.

Implant surface can also be bioactivated to improve its integration inside the bone tissue using a dual multilayer LBL coating: a first CHI-HA/poly-acrylic acid LBL coating to promote long term implant fixation and a Poly ( $\beta$-amino ester) acid (poly2)/BMP-2 coating to promote the primary osteoconductive integration [113].

Other types of specific structures can be engineered using the LBL technique: Silva et al. were able to build a multilayered $\mathrm{CHI} /$ chondroitine sulphate scaffold deposited on paraffin beads construct. After the beads leaching, a highly porous multilayered scaffold was obtained exhibiting viscous-plastic mechanical properties close to those of cartilage and a good chondrogenic potential on adult chondrocytes and mesenchymal stem cells [112]. Crouzier et al. have coated macroporous tricalcium phosphate/HA granules with a biopolyelectrolyte multilayer film to deliver rhBMP-2, with positive osteoconductive and osteoinductive properties [114].

\section{Conclusion and Perspectives}

The recent developments of nanotechnology have a strong impact on the regenerative medicine and tissue engineering fields. Nanostructures presented in this review and their impacts on the cells fate have been summarized in the Table 1. Biomaterials can nowadays present designed structures from the macroscopic to the nanoscopic scale and allowing better biomimetic environment for the developing tissues. However, many problems still need to be solved.

First, despite the development of sophisticated strategies to engineer micro and nano orientated structures, to engineer crosslinks, to incorporate nanotubes and nanocrystals, the polymer scaffolds generally present insufficient mechanical properties to resist the biomechanical environment of the osteochondral tissues and are unable to replace the tissues function. In a situation of high mechanical stresses, the cells are not able to proliferate and to behave properly and the tissue regeneration will be jeopardized. In the case of the replacement of the full osteochondral unit (hyaline cartilage and subchondral bone), the problem is more acute as the mechanical properties need to evolve from a soft, porous tissue to a rigid mineralized one.

Second, the development of nanoparticles, complex microspheres and multilayered nanoreservoirs is a huge opportunity to cleverly biofunctionalize the synthetic scaffolds and to drive the cell behavior and tissue regeneration, but investigations will need to focus on the fine tuning of the temporal and spatial delivery of the growth factors, the building of gradients and the development of factors co-delivery systems to promote synergic actions of the growth factors. Such strategies are of great importance for the development of complex cellular systems like the osteochondral unit: promoting on one side the development of chondrocytes and cartilage ECM in an avascular environment and on the other side, the development of a well vascularized bone tissue with osteoblasts, osteoclasts.

Finally, one more problem to solve is the proper implantation of the scaffolds within the defects in a clinical situation. Indeed, weak fixation of the scaffold will lead to improper mechanical loading of the implant and its damaging, compromising the success of the intervention. A close team work between biologists, material engineers and the surgeons is required via pre-clinical investigations to ensure the clinical viability of the bio scaffolds. In the pre-clinical aspect, there is also a lack of standard screening conditions for reliable comparison purposes between all the studies, for instance, there is no consensus in the choice of animal model for in vivo studies.

Primarily focused on the restoration of small osteochondral defects, all these nanotechnologies will surely evolve towards improvement of osteochondral biomechanical function in restored tissue, and will eventually enable the repair of larger defects and possibly the resurfacing of a whole joint.

\section{References}

1. Geiger M, Li R, Friess W (2003) Collagen sponges for bone regeneration with rhBMP-2. Collagen in drug delivery and tissue engineering 55: 1613-1629.

2. Allo BA, Costa DO, Dixon SJ, Mequanint K, Rizkalla AS (2012) Bioactive and Biodegradable Nanocomposites and Hybrid Biomaterials for Bone Regeneration. Journal of Functional Biomaterials 3: 432-463.

3. Panseri S, Russo A, Cunha C, Bondi A, Di Martino A, et al. (2012) Osteochondral tissue engineering approaches for articular cartilage and subchondral bone regeneration. Knee Surgery, Sports Traumatology, Arthroscopy 20: 1182-1191.

4. Temenoff JS, Mikos AG (2000) Review: tissue engineering for regeneration of articular cartilage. Biomaterials 21: 431-440 
Citation: Schwinté P, Keller L, Lemoine S, Gottenberg JE, Benkirane-Jessel N, et al. (2015) Nano-Engineered Scaffold for Osteoarticular Regenerative Medicine. J Nanomed Nanotechnol 6: 258. doi: 10.4172/2157-7439.1000258

Page 7 of 9

5. Van Osch GJVM, Brittberg M, Dennis JE, Bastiaansen-Jenniskens YM, Erben RG, et al. (2009) Cartilage repair: past and future-lessons for regenerative medicine. Journal of Cellular and Molecular Medicine 13: 792-810.

6. Metzger W, Schwab B, Miro M, Grad S, Simpson A, et al. (2014) Induction of Osteogenic Differentiation by Nanostructured Alumina Surfaces. Journal of biomedical nanotechnology 10: 831-845.

7. Watari S, Hayashi K, Wood JA, Russell P, Nealey PF, et al. (2012) Modulation of osteogenic differentiation in hMSCs cells by submicron topographicallypatterned ridges and grooves. Biomaterials 33: 128-136.

8. Dvir T, Timko BP, Kohane DS, Langer R (2011) Nanotechnological strategies for engineering complex tissues. Nature Nanotechnology 6: 13-22.

9. Kane R, Ma PX (2013) Mimicking the nanostructure of bone matrix to regenerate bone. Materials Today 16: 418-423.

10. Gusic N, Ivkovic A, VaFaye J, Vukasovic A, Ivkovic J, et al. (2014) Nanobiotechnology and bone regeneration: a mini-review. International Orthopaedics 38: 1877-1884.

11. Lim JY, Loiselle AE, Lee JS, Zhang Y, Salvi JD, et al. (2011) Optimizing the osteogenic potential of adult stem cells for skeletal regeneration. Journal of Orthopaedic Research 29: 1627-1633.

12. Moradi O, Yari M, Zare K, Mirza B, Najafi F (2012) Carbon Nanotubes: A Review of Chemistry Principles and Reactions. Fullerenes, Nanotubes and Carbon Nanostructures. Taylor and Francis 20: 138-151.

13. Nayak TR, Andersen H, Makam VS, Khaw C, Bae S, et al. (2011) Graphene for Controlled and Accelerated Osteogenic Differentiation of Human Mesenchymal Stem Cells. ACS Nano 5: 4670-4678.

14. Depan D, Pesacreta TC, Misra RDK (2014) The synergistic effect of a hybrid graphene oxide-chitosan system and biomimetic mineralization on osteoblast functions. Biomater Sci 2: 264-274.

15. Sniadecki N, Desai R, Ruiz S, Chen C (2006) Nanotechnology for CellSubstrate Interactions. Annals of Biomedical Engineering 34: 59-74.

16. Moradi O, Aghaie M, Zare K, Monaijemi M, Aghaie H (2009) The study of adsorption characteristics $\mathrm{Cu} 2+$ and $\mathrm{Pb} 2+$ ions onto $\{\mathrm{PHEMA}\}$ and $\mathrm{P}(\mathrm{MMA}$ HEMA) surfaces from aqueous single solution. Journal of Hazardous Materials 170: 673-679.

17. Elsagh A, Moradi O, Fakhri A, Najafi F, Alizadeh R, et al. (2013) Evaluation of the potential cationic dye removal using adsorption by graphene and carbon nanotubes as adsorbents surfaces. Arabian Journal of Chemistry: -

18. Zhang S, Uludag H (2009) Nanoparticulate Systems for Growth Factor Delivery. Pharmaceutical Research 26: 1561-1580.

19. Wang X, Wenk E, Zhang X, Meinel L, Vunjak-Novakovic G, et al. (2009) Growth factor gradients via microsphere delivery in biopolymer scaffolds fo osteochondral tissue engineering. Journal of Controlled Release 134: 81-90.

20. Rho JY, Kuhn-Spearing L, Zioupos $P$ (1998) Mechanical properties and the hierarchical structure of bone. Medical Engineering and Physics 20: 92-102.

21. Augat $P$, Schorlemmer $S$ (2006) The role of cortical bone and its microstructure in bone strength. Age and Ageing 35: ii27-ii31.

22. Currey J (2004) Incompatible mechanical properties in compact bone. Journal of Theorical Biology 231: 569-580.

23. Zioupos P, Currey JD, Hamer AJ (1999) The Role of Collagen in the Declining Mechanical Properties of Aging Human Cortical Bone. Journal of Biomedical Materials Research, Part A 45: 108-116.

24. Wang X, Shen X, Li X, Mauli Agrawal C (2002) Age-related changes in the collagen network and toughness of bone. Bone 31: 1-7.

25. Rho JY, Zioupos P, Currey JD, Pharr GM (2002) Microstructural Elasticity and Regional Heterogeneity in Human Femoral Bone of Various Ages Examined by Nanoindentation. Journal of Biomechanics 35: 189-198.

26. Fan Z, Swadener JG, Rho JY, Roy ME, Pharr GM (2002) Anisotropic properties of human tibial cortical bone as measured by nanoindentation. Journal of Orthopaedic Research 20: 806-810.

27. Oyen ML, Ferguson VL, Bembey AK, Bushby AJ, Boyde A (2008) Composite bounds on the elastic modulus of bone. Journal of Biomechanics 41: 2585-
28. Cowin SC, Doty SB (2007) Tissue Mechanics. Springer Sciences+Business Media: 471-506.

29. Ghosh S, Kaplan DL (2008) Chapter 36: In Vitro 3D Human Tissue Models for Osteochondral Diseases.

30. Gupta HS, Schratter S, Tesch W, Roschger P, Berzlanovich A, et al. (2005) Two different correlations between nanoindentation modulus and mineral content in the bone-cartilage interface. Journal of Structural Biology 149: 138-148.

31. Gomoll A, Madry H, Knutsen G, Dijk N, Seil R, et al. (2010) The subchondra bone in articular cartilage repair: current problems in the surgical management. Knee Surgery, Sports Traumatology, Arthroscopy 18: 434-447.

32. Hutmacher DW, Schantz JT, Lam CXF, Tan KC, Lim TC (2007) State of the art and future directions of scaffold-based bone engineering from a biomaterials perspective. Journal of Tissue Engineering and Regenerative Medicine 1: 245-260.

33. Stevens MM (2008) Biomaterials for bone tissue engineering. Materials Today 11: $18-25$.

34. Lee J, Cuddihy MJ, Kotov NA (2008) Three-Dimensional Cell Culture Matrices: State of the Art. Tissue Engineering part B 1: 61-86.

35. Rezwan K, Chen QZ, Blaker JJ, Boccaccini AR (2006) Biodegradable and bioactive porous polymer/inorganic composite scaffolds for bone tissue engineering. Biomaterials 27: 3413-3431.

36. Parenteau-Bareil R, Gauvin R, Berthod F (2010) Collagen-Based Biomaterials for Tissue Engineering Applications. Materials 3: 1863-1887.

37. Liu X, Rahaman MN, Fu Q (2013) Bone regeneration in strong porous bioactive glass (13-93) scaffolds with an oriented microstructure implanted in rat calvarial defects. Acta Biomaterialia 9: 4889-4898.

38. Geesink RG (2002) Osteoconductive coatings for total joint arthroplasty. clinica orthopeadics and related research 395: 53-65.

39. Damien E, Hing K, Saeed S, Revell PA (2003) A preliminary study on the enhancement of the osteointegration of a novel synthetic hydroxyapatite scaffold in vivo. Journal of Biomedical Materials Research Part A 66A: 241-246.

40. Rahaman MN, Day DE, Sonny Bal B, Fu Q, Jung SB, et al. (2011) Bioactive glass in tissue engineering. Acta Biomaterialia 7: 2355-2373.

41. Jones JR (2013) Review of bioactive glass: From Hench to hybrids. Acta Biomaterialia 9: 4457-4486.

42. Hutmacher DW (2000) Scaffolds in tissue engineering bone and cartilage Orthopaedic Polymeric Biomaterials: Applications of Biodegradables 21: 2529 2543.

43. Rhee SH, Choi JY, Kim HM (2002) Preparation of a bioactive and degradable poly(e-caprolactone)/silica hybrid through a sol-gel method. Biomaterials 23 4915-4921.

44. Inzana JA, Olvera D, Fuller SM, Kelly JP, Graeve OA, et al. (2014) 3D printing of composite calcium phosphate and collagen scaffolds for bone regeneration. Biomaterials 35: 4026-4034.

45. Levingstone TJ, Matsiko A, Dickson GR, O'Brien FJ, Gleeson JP (2014) A biomimetic multi-layered collagen-based scaffold for osteochondral repair. Acta Biomaterialia 10: 1996-2004.

46. Jiang J, Tang A, Ateshian G, Guo XE, Hung C, et al. (2010) Bioactive Stratified Polymer Ceramic-Hydrogel Scaffold for Integrative Osteochondral Repair Annals of Biomedical Engineering 38: 2183-2196.

47. Qu D, Li J, Li Y, Khadka A, Zuo Y, et al. (2011) Ectopic osteochondral formation of biomimetic porous PVA-n-HA/PA6 bilayered scaffold and BMSCs construct in rabbit. Journal of Biomedical Materials Research Part B: Applied Biomaterials 96B: 9-15.

48. Harley BA, Lynn AK, Wissner-Gross Z, Bonfield W, Yannas IV, et al. (2010) Design of a multiphase osteochondral scaffold III: Fabrication of layered scaffolds with continuous interfaces. Journal of Biomedical Materials Research Part A 92A: 1078-1093.

49. Martin TA, Caliari SR, Williford PD, Harley BA, Bailey RC (2011) The generation of biomolecular patterns in highly porous collagen-GAG scaffolds using direct photolithography. Biomaterials 32: 3949-3957.

50. McCafferty MM, Burke GA, Meenan BJ (2014) Calcium phosphate thin films enhance the response of human mesenchymal stem cells to nanostructured titanium surfaces. Journal of Tissue engineering 5 . 
51. Nune KC, Misra RD (2014) Pre-adsorption of protein on electrochemically grooved nanostructured stainless steel implant and relationship to cellular activity. Journal of Biomedical Nanotechnology 10: 1320-1335.

52. Kim J, Bae WG, Choung HW, Lim KT, Seonwoo H, et al. (2014) Multiscale patterned transplantable stem cell patches for bone tissue regeneration. Biomaterials 35: 9058-9067.

53. Pennisi C, Zachar V, Fink T, Gurevich L, Fojan P (2013) Patterned Polymeric Surfaces to Study the Influence of Nanotopography on the Growth and Differentiation of Mesenchymal Stem Cells. In Turksen K, editor. Stem Cell Nanotechnology. Humana Press 1058: 77-88.

54. Mendes PM (2013) Cellular nanotechnology: making biological interfaces smarter. Chemical Society Reviews 42: 9207-9218.

55. Li X, Cui R, Liu W, Sun L, Yu B, et al. (2013) The Use of Nanoscaled Fibers or Tubes to Improve Biocompatibility and Bioactivity of Biomedical Materials. Journal of Nanomaterials 2013: 1-16.

56. Facca S, Lahiri D, Fioretti F, Messadeq N, Mainard D, et al. (2011) In Vivo Osseointegration of Nano-Designed Composite Coatings on Titanium Implants. ACS Nano 5: 4790-4799.

57. Frandsen CJ, Brammer KS, Noh K, Johnston G, Jin S (2014) Tantalum coating on TiO2 nanotubes induces superior rate of matrix mineralization and osteofunctionality in human osteoblasts. Materials Science and Engineering: C 37: 332-341.

58. Brammer KS, Oh S, Frandsen CJ, Varghese S, Jin S (2010) Nanotube surface triggers increased chondrocyte extracellular matrix production. Materials Science and Engineering: C 30: 518-525.

59. Im O, Li J, Wang M, Zhang LG, Keidar M (2012) Biomimetic three-dimensiona nanocrystalline hydroxyapatite and magnetically synthesized single-walled carbon nanotube chitosan nanocomposite for bone regeneration. International Journal of Nanomedicine 7: 2087-2099.

60. Shamsudin M, Mohammad M, Zobir S, Asli N, Bakar S, et al. (2013) Synthesis and nucleation-growth mechanism of almost catalyst-free carbon nanotubes grown from Fe-filled sphere-like graphene-shell surface. Journal of Nanostructure in Chemistry 3.

61. Nishida E, Miyaji H, Takita H, Kanayama I, Tsuji M, et al. (2014) Graphene oxide coating facilitates the bioactivity of scaffold material for tissue engineering. Japanese Journal of Applied Physics 53: 06JD04.

62. Hiranandani D, Ghosh B, Salimath A (2014) Effect of microscopic ripples on spin relaxation length in single-layer graphene. Journal of Nanostructure in Chemistry 4. Available:

63. Danilov MO, Slobodyanyuk IA, Rusetskii IA, Kolbasov GY (2013) Synthesis of reduced graphene oxide and its electrocatalytic properties. Russian Journal of Applied Chemistry 86: 858-862.

64. Chandiramouli R, Gopinath P, Sriram S (2014) Investigation on electronic transport property of cerium nitride nanoribbon-based molecular device: a firstprinciples study. Journal of Nanostructure in Chemistry 4.

65. Talukdar Y, Rashkow JT, Lalwani G, Kanakia S, Sitharaman B (2014) The effects of graphene nanostructures on mesenchymal stem cells. Biomaterials 35: 4863-4877.

66. Bao H, Pan Y, Ping Y, Sahoo NG, Wu T, et al. (2011) Chitosan-Functionalized Graphene Oxide as a Nanocarrier for Drug and Gene Delivery. Small 7: 15691578

67. Teo WE, Inai R, Ramakrishna $S$ (2011) Technological advances in electrospinning of nanofibers. Science and Technology of Advanced Materials 12: 013002.

68. Ferrand A, Eap S, Richert L, Lemoine S, Kalaskar D, et al. (2013) Osteogenetic Properties of Electrospun Nanofibrous PCL Scaffolds Equipped With ChitosanBased Nanoreservoirs of Growth Factors. Macromolecular Bioscience 14: 4555.

69. Sachar A, Strom TA, Serrano MJ, Benson MD, Opperman LA, et al. (2012) Osteoblasts responses to three-dimensional nanofibrous gelatin scaffolds. Journal of Biomedical Materials Research Part A 100A: 3029-3041.

70. Schneider RK, Puellen A, Kramann R, Raupach K, Bornemann J, et al. (2010) The osteogenic differentiation of adult bone marrow and perinatal umbilical mesenchymal stem cells and matrix remodelling in three-dimensional collagen scaffolds. Biomaterials 31: 467-480.
71. Wei G, Ma PX (2004) Structure and properties of nano-hydroxyapatite/polymer composite scaffolds for bone tissue engineering. Biomaterials 25: 4749-4757.

72. Lee SS, Huang BJ, Kaltz SR, Sur S, Newcomb CJ, et al. (2013) Bone regeneration with low dose BMP-2 amplified by biomimetic supramolecular nanofibers within collagen scaffolds. Biomaterials 34: 452-459.

73. Woo KM, Jun JH, Chen VJ, Seo J, Baek J, et al. (2007) Nano-fibrous scaffolding promotes osteoblast differentiation and biomineralization. Cellula and Molecular Biology Techniques for Biomaterials Evaluation 28: 335-343.

74. Drury JL, Mooney DJ (2003) Hydrogels for tissue engineering: scaffold design variables and applications. Synthesis of Biomimetic Polymers 24: 4337-4351.

75. Forgacs G, Newman SA, Hinner B, Maier CW, Sackmann E (2003) Assembly of Collagen Matrices as a Phase Transition Revealed by Structural and Rheologic Studies. Biophysical journal 84: 1272-1280.

76. Shah RN, Shah NA, Del Rosario Lim MM, Hsieh C, Nuber G, et al. (2010) Supramolecular design of self-assembling nanofibers for cartilage regeneration. Proceedings of the National Academy of Sciences 107: 3293-3298.

77. Liu J, Song H, Zhang L, Xu H, Zhao X (2010) Self-Assembly-Peptide Hydrogels as Tissue-Engineering Scaffolds for Three-Dimensional Culture of Chondrocytes in vitro. Macromolecular Bioscience 10: 1164-1170.

78. Kopesky PW, Vanderploeg EJ, Sandy JS, Kurz B, Grodzinsky AJ (2010) SelfAssembling Peptide Hydrogels Modulate In Vitro Chondrogenesis of Bovine Bone Marrow Stromal Cells. Tissue Engineering Part A 16: 465-477.

79. Getgood A, Brooks R, Fortier L, Rushton N (2009) Articular cartilage tissue engineering: today's research, tomorrow's practice? J Bone Joint Surg $\mathrm{Br} 91$ 565-576.

80. Thomas V, Dean DR, Jose MV, Mathew B, Chowdhury S, et al. (2007) Nanostructured Biocomposite Scaffolds Based on Collagen Coelectrospun with Nanohydroxyapatite. Biomacromolecules 8: 631-637.

81. Yilgor P, Tuzlakoglu K, Reis RL, Hasirci N, Hasirci V (2009) Incorporation of a sequential BMP-2/BMP-7 delivery system into chitosan-based scaffolds for bone tissue engineering. Biomaterials 30: 3551-3559.

82. Lai GJ, Shalumon KT, Chen SH, Chen J-P (2014) Composite chitosan/silk fibroin nanofibers for modulation of osteogenic differentiation and proliferation of human mesenchymal stem cells. Carbohydrate Polymers 111: 288-297.

83. Mendoza-Palomares C, Ferrand A, Facca S, Fioretti F, Ladam G, et al. (2011) Smart Hybrid Materials Equipped by Nanoreservoirs of Therapeutics. ACS Nano 6: 483-490.

84. McCullen SD, Autefage H, Callahan A, Gentleman E (2012) Anisotropic Fibrous Scaffolds for Articular Cartilage Regeneration. Tissue Engineering Part A 18 2073-2083.

85. Accardi MA, Autefage H, McCullen SD, Callahan A, Chung S, et al. (2013) Effects of Fiber Orientation on the Frictional Properties and Damage of Regenerative Articular Cartilage Surfaces. Tissue Engineering Part A 19: 23002310 .

86. Steele JA, McCullen SD, Callahan A, Autefage H, Accardi MA, et al. (2014) Combinatorial scaffold morphologies for zonal articular cartilage engineering Acta Biomaterialia 10: 2065-2075.

87. Tetteh G, Khan AS, Delaine-Smith RM, Reilly GC, Rehman IU (2014) Electrospun polyurethane/hydroxyapatite bioactive Scaffolds for bone tissue engineering: The role of solvent and hydroxyapatite particles. Journal of the Mechanical Behavior of Biomedical Materials 39: 95-110.

88. Shao S, Zhou S, Li L, Li J, Luo C, et al. (2011) Osteoblast function on electrically conductive electrospun PLA/MWCNTs nanofibers. Biomaterials 32: 2821-2833.

89. Torricelli P, Gioffrè M, Fiorani A, Panzavolta S, Gualandi C, et al. (2014) Coelectrospun gelatin-poly(I-lactic acid) scaffolds: Modulation of mechanical properties and chondrocyte response as a function of composition. Materials Science and Engineering: C 36: 130-138.

90. Thorvaldsson A, Stenhamre H, Gatenholm P, Walkenström P (2008) Electrospinning of Highly Porous Scaffolds for Cartilage Regeneration. Biomacromolecules 9: 1044-1049.

91. Schneider T, Kohl B, Sauter T, Kratz K, Lendlein A, et al. (2012) Influence of fiber orientation in electrospun polymer scaffolds on viability, adhesion and differentiation of articular chondrocytes. Clinical Hemorheology and Microcirculation 52: 325-336. 
Citation: Schwinté P, Keller L, Lemoine S, Gottenberg JE, Benkirane-Jessel N, et al. (2015) Nano-Engineered Scaffold for Osteoarticular Regenerative Medicine. J Nanomed Nanotechnol 6: 258. doi: 10.4172/2157-7439.1000258

92. Stanishevsky A, Chowdhury S, Chinoda P, Thomas V (2008) Hydroxyapatite nanoparticle loaded collagen fiber composites: Microarchitecture and nanoindentation study. Journal of Biomedical Materials Research Part A 86A: 873-882.

93. Catledge SA, Clem WC, Shrikishen N, Chowdhury S, Stanishevsky AV, et al. (207AD) An electrospun triphasic nanofibrous scaffold for bone tissue engineering. Biomedical Materials 2: 142.

94. Choumerianou DM, Dimitriou H, Kalmanti M (2008) Stem Cells: Promises Versus Limitations. Tissue Engineering Part B: Reviews 14: 53-60.

95. Zhao C, Tan A, Pastorin G, Ho HK (2013) Nanomaterial scaffolds for stem cell proliferation and differentiation in tissue engineering. Pearl (30th) Anniversary Edition: Nanotechnology \& Regenerative Medicine 31: 654-668.

96. McCullen SD, Haslauer CM, Loboa EG (2010) Musculoskeletal mechanobiology: Interpretation by external force and engineered substratum. Special Issue on Cell Mechanobiology 43: 119-127.

97. O'Conor C, Case N, Guilak F (2013) Mechanical regulation of chondrogenesis Stem Cell Research \& Therapy 4: 1-13.

98. Zhong W, Zhang W, Wang S, Qin J (2013) Regulation of Fibrochondrogenesis of Mesenchymal Stem Cells in an Integrated Microfluidic Platform Embedded with Biomimetic Nanofibrous Scaffolds. PLoS ONE 8: e61283.

99. Engler AJ, Sen S, Sweeney HL, Discher DE (2006) Matrix Elasticity Directs Stem Cell Lineage Specification. Cell 126: 677-689.

100. Lee S-H, Shin H (2007) Matrices and scaffolds for delivery of bioactive molecules in bone and cartilage tissue engineering. Matrices and Scaffolds for Drug Delivery in Tissue Engineering 59: 339-359.

101.Luca L, Rougemont A-L, Walpoth BH, Gurny R, Jordan O (2010) The effects of carrier nature and $\mathrm{pH}$ on rhBMP-2-induced ectopic bone formation. Journal of Controlled Release 147: 38-44.

102. Kopesky PW, Byun S, Vanderploeg EJ, Kisiday JD, Frisbie DD (2014) Sustained delivery of bioactive TGF- $\beta 1$ from self-assembling peptide hydrogels induces chondrogenesis of encapsulated bone marrow stromal cells. 10: 1275-1285.

103. Bökel C, Brown NH (2002) Integrins in Development: Moving on, Responding to, and Sticking to the Extracellular Matrix. Developmental Cell 3: 311-321.
104. Holland TA, Bodde EWH, Baggett LS, Tabata Y, Mikos AG, et al. (2005) Osteochondral repair in the rabbit model utilizing bilayered, degradable oligo(poly(ethylene glycol) fumarate) hydrogel scaffolds. Journal of Biomedical Materials Research Part A 75A: 156-167.

105. Dormer N, Singh M, Wang L, Berkland C, Detamore M (2010) Osteochondra Interface Tissue Engineering Using Macroscopic Gradients of Bioactive Signals. Annals of Biomedical Engineering 38: 2167-2182.

106.Zhang S, Kucharski C, Doschak MR, Sebald W, Uludag H (2010) Polyethylenimine-PEG coated albumin nanoparticles for BMP-2 delivery. Biomaterials 31: 952-963.

107.Niu X, Feng Q, Wang M, Guo X, Zheng Q (2009) Porous nano-HA/collagen/ PLLA scaffold containing chitosan microspheres for controlled delivery of synthetic peptide derived from BMP-2. Journal of Controlled Release 134 111-117.

108. Choi DH, Park CH, Kim IH, Chun HJ, Park K, et al. (2010) Fabrication of coreshell microcapsules using PLGA and alginate for dual growth factor delivery system. Journal of Controlled Release 147: 193-201.

109. Bock N, Riminucci A, Dionigi C, Russo A, Tampieri A, et al. (2010) A novel route in bone tissue engineering: Magnetic biomimetic scaffolds. Acta Biomaterialia 6: 786-796.

110. A Tampieri and $E$ Landi and $F$ Valentini and $M$ Sandri and T D'Alessandro and $V$ Dediu and M Marcacci (2011) A conceptually new type of bio-hybrid scaffold for bone regeneration. Nanotechnology 22: 015104

111. Facca S, Cortez C, Mendoza-Palomares C, Messadeq N, Dierich A, et al (2010) Active multilayered capsules for in vivo bone formation. Proceedings of the National Academy of Sciences 107: 3406-3411.

112. Silva JM, Georgi N, Costa R, Sher P, Reis RL, et al. (2013) Nanostructured 3D Constructs Based on Chitosan and Chondroitin Sulphate Multilayers for Cartilage Tissue Engineering. PLoS ONE 8: eSS451.

113. Shah NJ, Hyder MN, Moskowitz JS, Quadir MA, Morton SW, et al (2013) Surface-Mediated Bone Tissue Morphogenesis from Tunable Nanolayered Implant Coatings. Science Translational Medicine 5: 191ra83.

114. Crouzier T, Sailhan F, Becquart P, Guillot R, Logeart-Avramoglou D, et al. (2011) The performance of BMP-2 loaded TCP/HAP porous ceramics with polyelectrolyte multilayer film coating. Biomaterials 32: 7543-7554. 